DRUMIIOND, CALGAREOUS DISEASE OF HEART. 153

strongly and with as much confidence, as a diuretic, as I can as a perfect anti-emetic.

I recall the fact tbat cocaine did act as a "heart-tonic and stimulant" in my cases of yellow fever, but filled to note it at the time, being more occupied with its action in quieting the stomach nnd keeping up the setion of the kidneys.

In summing up the value of cocaine in the treatment of yellow fever, it may be stated to be almost a specific, in my experience doing more to cure this disense than any otber drug I have ever tried, taking away or removing all nausen and vomiting, acting as a diuretic and as an excellent and sure "henrt-tonic ind stimulant."

\title{
NOTES OF A CASE OF CALCAREOUS DISEASE OF THE HEART AND PERICARDIOAY.
}

\author{
By David Drumsonn, Mr.A., MI.D.

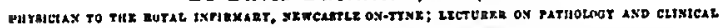

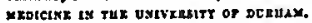

Tre difficulties attcnding the diagnosis of the case I am about to relate, and its undoubted rarity, are sufficient grouads for the supposition that it will prove of interest to the profession.

Robert G., aged forty-three, a sailor, married, three children, was admitted into the Royal Infirmary, Newcastle-on'Tyne, for cough and sbortness of breatb.

According to the paticnt's statement his illness began fourteen weeks before bis admission into bospital, with cough and copious expectoration, due to catching cold, to which for some years be had been liable. $\mathrm{He}$ was at sea at the time, and thougb sufiering, was able to continue bis em. ployment for four or five weeks longer, when increasing sbortness of breath and sirelling of the legs compelled bim to seek rest and medical ndvice ashore. He now observed swelliag of the epigastric region, and deepening in the hue of his already florid countenance. The howels were constipated; the appetite remained moderate, but he steadily lost flesh. From the heginning he experienced little or no pain.

Present condition.-There is decided emaciation. Legs are codematous. The face is cyanotic, and wears an anxious expression. The right pupil is smaller than the left. The breathing is short and rapid (thirty-two in the minute). The cough is frequent, and accompanying it is a copious, colorless, frothy expectoration. He lies on his rigbt side, nnd is obviously inconvenienced by the essumption of any other decuhitus. The pulse is irregular and wenk, eighty-four at the wrist, one hundred wben counted with the stethoscope. Temperature normal. He has no pain; his sole conplaint is of irritating cough and dyspnoer.

Chest.-Heart impulse diffused and heaving, hut most distinct in epigastrium and ahout two and one-half inches below the left nipple. The 
heart's action is irregular and tumultuous, and there is a want of clearness and precision ahout the sounds. A short systolic murmur can be heard at the apex, having no special line of conduction, and another of corresponding rhythm in the tricuspid aren. The aortic sounds are very obscure, hut seem to be unaccompanied hy murmur. The limits of cardiac dulness are masked hy cmphysema of the left lung on the one hand, nnd by an area of dulness occupying the front of the right cbest on the other. This region is dull on percussion from the first rib down to the liver, and the dulness is absolute in the neighborhood of the third and fourth ribs, one and a balf inches to the right of the sternum, where the chest-wull is more prominent than elsewhere. Herc tbe intercostal spaces are obliterated by coma, which passes down into the right bypochondrium, and the veins are full and tortuous. The left chest is resonant in front. The hreath sounds are feehle and distant over the dull aren to the right of the sternum, espccinlly townrd the lower part. At the apex the sounds arc larsh and accompanied by rloonchi, which are obviously conducted from the left side, where rhonchi nad puerile hreathiag prevail. Vocal fremitus and resoannee are diminished on the right side. At the hack hoth sides are fairly resonant on pereussioa, with the exception of an aren to the riglit of the spinal column above the sixtl rib, whieh is dull. In this dull region the hrenth sounds are tubular though distant, whilst toward the hase where the aote is resonant, they are very feehle and indistiact though aecompanied hy râle. To the left of the spine the sounds are liarsh as ia front, The roice fremitus aad resoanace are tolerally well narked on hoth sides, and about equal. On iatrodueiag a fine lypodermie needle into tle dull area on the right. side in froat, some clenr hlood-staiaed fluid was withdrawn.

Aldomen.-The epigastriun and right liypoelıondrium are full and prominent, espeeially the latter where the skii is cedematous. The liver is much enlarged and can easily be felt four and a half iuches helow the sterausa in tlie middle line, uad four inches below the arell of the ribs in the riglit mammary line. The enlargement is smooth and puinles, and is hut little influeaced by respiratory movements. A consideralble quantity of free fluid in the peritonenl cavity. No increase in splenic dulness. The urioe is high-colored and scanty, hut is free from albu. min. The temperature is pratically normal.

Previous illnesses.-Has hind cough from time to time sinee he was a youth, but he attached little importance to it. Of late years a winter cough troubled him a good deal. Never suffered from rheumatism or syphilis.

Family history.-Is good; no tubercular diseases that he is aware of.

By degrees the dyspnan became more distressing and the cymosis increased. On Fchruary 17 th, a week after his admission, the expectoration was ohserred to be blood-stained, and from this time up to his death it usually contained blood, heing frequently "prune-juice" in color.

On the 19th, the chest was tapped in front, nnd seventeen ounces of bloody serum were drawn off, which was followed-hy a certain degree of relief. The cynnosis deepened rapidly toward the end, and without any very significant change in the physical signs to record, he died on the 21 st of Fehruary, twelve dnys after admission into the hospital. 
DRUYMOND, CALCAREOUS DISEASE OF HEART. 155

Post-mortem examination, about twenty-gix hours after death. Rigor mortis passing off. Fneo and dependent portions of the body livid. Legs odematous. Abdoniea disteaded; $n$ considerable quantity of bloodstained fluid escaped on openiag peritoscum. The sternum was raised with difficulty owing to deose adhesions. The unterior medinstinum was oceupied hy a lnrge hard moss that at first sight appeared to he a tumor. The right lung was partially collapsed and the anterior portion of its pleural cavity contained bloody fluid. It was adbereat toward the base-to the chest-wnll posteriorly, und to the laard mass in

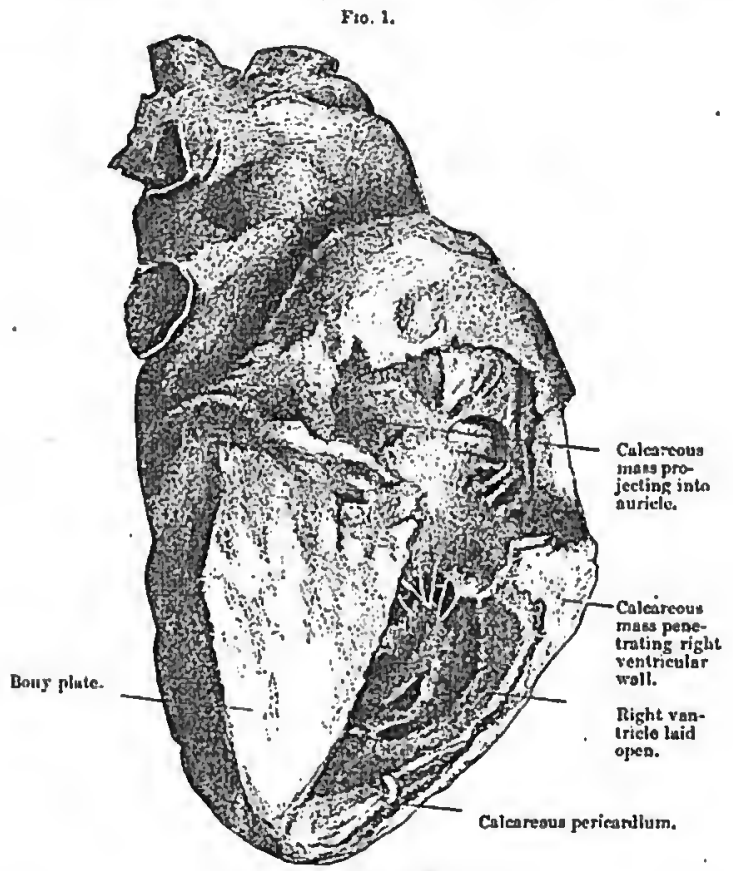

Right veatricle, posterior view.

the medinstinum. The pleurn was an eighth of on ineh thick. The left lung wns emphysemntous $n$ nd fre from adhesioas; frothy serum cxuded from its cut surfuee. 
On removing the cooteots of the mediastinum, which were very firmly nttached behind (spioc), to the right (lung), and below (diaphragm), the lond mass filling its lower two-thirds was recognized to be the heart with its pericardinl sac ndherent. The whole, divested of extrancous structures, weighed one pound and ten ounces.

Fio. 2.

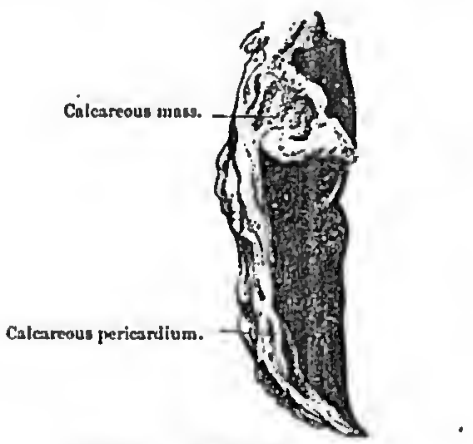

Section of rentricular wall.

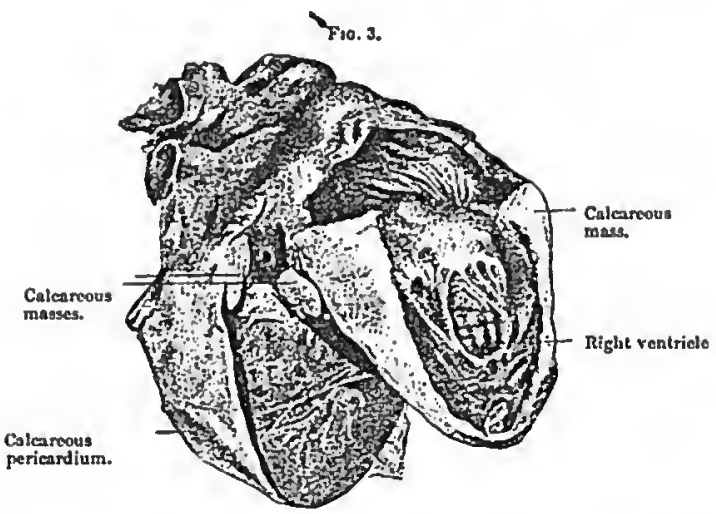

The position occupied by the beart in the body mas somewhat un. usual. It lny almost horizontal, the level of the opex being very slightly 
helow that of the hase. Its shape was peculiar. It was markedly flatteaed from hefore backward, and was distinetly wider transversely than from hase to apex; it measured, for example, four and a balf inches across, and only four inches from hase of aorta to npex of left ventricle. The diaphragmatic surface (the true posterior surface) was perfectly flat nnd triangular in shspe. It had been closely attached to the diaphragm and measured three inches from hase to a pex, with a hasic line of three and a half inches. This surface was one solid plate of calcareous material, and had to be cut with a aaw. Speaking generally, the outer layer of the parietal pericardium could be dissected off the heart as a memhrane, leaving an inner layer firmly adherent and calcareous. In places certainly the whole of the parietal pericardium was membranous, particularly over the upper and posterior part of the right rentricle, and again in other places hoth the parietal and visceral divisions of the sac were memhranous, e.g., on the anterior surface. On removing all that could he dissected of the pericardium, the heart-wnlls were seen to he composed largely of calcareous matter, arranged irregularly in nodular masses. This materinl was most ahundant at the hack and toward the right side of the organ. Running ncross the front of the left ventricle was a thick ridge of bone-like substance. In some places this was an inch in breadth and in others half an iuch. It penetrated deeply into the hesrt muscle, especially toward the left side, where a redge shaped nodule the size of a walnut (see Fig. 2) passed quite through the heart, its aper presenting prominently among the columnx carnese.

This ridge was firmly attsched nt both ends to the great bony case that enveloped the heart. The whole of the right ventricle was encused in a dense calcareous envelope, and, as hefore stated, had to be opened. with a saw. The walls of this case varied from a quarter of an inch to nn inch in thickness, and they were intimntely incorporated with the heart muscle. On its surface were sereral eavities, the size of small filherts, that contrined putty-like material. 'The whole of the left uuricle was practically memhranous, but the calcareous case encroached to $n$ considerahle extent upon the right auricle, chieily its posterior surface, in the neighhorbood of the entrance of the iaferior vena cava. One nodule penetrated hetween the musculi pectinati, appearing as a yellow mass on the internal surface of the nuricle, covered only by $n$ thin layer of endocardiun.

The myocardium generally was friable and pale. The aortic and pulmoanry valves were competent, and hoth vessels were henlthy. The tricuspid orifice admitted five fingers, aud the mitral four. The nitral curtains were somewhat thickened. The nuricles were dilated, especially the right, hut no material alteration in the size of the other cavities was ohserved. The walls of the left ventricle were considerably hypertrophied. The coronary artery was highly ntheromatous.

The kidneys and spleen were good examples of the changes that arise. from chronic veaous stangig.

The liver was large (four pounds, ten ounces), firm to the touch, and on section presented the usual nutmeg nppearances, whilst, in addition, the interstitial substaace was increased (finely granular cirrhotic). Scattered sparsely throughout its substance werc some pale gray nodules, size of n pin's-head, that strongly suggested tubercle, hut with this 
exception there were no evidences of tuhercle found in the hody; nor werc there any traces of ayphilis.

The view taken of the condition of the heart was that the disease had originated as a non-rheumatic pericarditis, perhaps of a tuberculnr nnture, nnd that myocarditis followed, the deposit undergoing calcareous degeneration. The possibility of an old pyopericarditis with a large collection of pus was entertained, though the history of the case scarcely served to estahlish the occurrence of so severe $n$ lesion. The fact, also, that the process of calcification had so extensively invaded the cardinc muscle made it difficult to nccept the theory that the hony pericardium had arisen simply from inspissntion and calcification of incarcerated pus. Notwithetanding this difficulty, my post-mortem room experience of the changes thnt take plnce in the plcura in cases of old-standing empyemn that have heen left alone mnde me hesitate to discard it. Calcareous pericardium is undouhtedly $n$ rare lesion, nad it is one that has seldom, if ever, been diagnosticuted duriag life. Nor is it ensy to see bow the dingaosis could be made, except, perhnps, in a morc or less accidental way by the istroductios of un exploratory aeedlc.

The disease suggested by $n$ careful considerntion of the signs and symptoms of the preseat case was mediastival uew.growth. The age of the potient, marked cyanosis, locul edema, bulging of cbest-wall, dilata. tios of veins, and the preseuce of hlood-staised pleural effusion with bloody expectoration, all poisted to that cordition. It is a marvellons fnct that the patient was able to follow the arduous employment of a sailor before the mast without experieaciag any, or oaly comparatively trifling, inconvenience, when it is considered that for years the hony case must have interfered with ventricular contrnction.

\section{AURAL VERTIGO ENTIRELY AND PERAANENTLY RELIEVED BY EXCISION OF THE ME.UBRANA TYAIPANI AND THE MALLEUS. \\ By Charleg H. BuR.etT, A AI., M.D.,

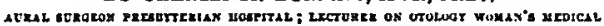 COLLEOS FHILADELFIHA.}

AUrat rertigo may be due to disease of the externol, the middle, or the internnl ear. The name "Menière'a disease" was originally applied to a disease of the internnl ear, characterized hy sudden nnd intense desfness, nausen nud vertigro, nnd to this form of aural vertigo it should still he limited. But mucl confusion has nrisen by applying the naine Ménière's disease to all forms of nural vertigo, regardless of their origin. The general term, however, should he nu ral vertigo, aud Ménière's dis- 